\title{
STUDIES OF ALKALOSIS. II. ELECTROLYTE ABNORMALITIES IN ALKALOSIS RESULTING FROM PYLORIC OBSTRUCTION ${ }^{1}$
}

\author{
BY CHARLES H. BURNETT, BELTON A. BURROWS,2 ROBERT R. COMMONS, \\ AND BEVERLY T. TOWERY *
}

\author{
(From the Evans Memorial, Massachusetts Memorial Hospitals; the Department of Medicine, \\ Boston University School of Medicine; the Thorndike Memorial Laboratory, Second \\ and Fourth Medical Services [Harvard], Boston City Hospital; and the \\ Department of Medicine, Harvard Medical School, Boston)
}

(Received for publication July 14, 1949)

\section{INTRODUCTION}

It has been clearly established in experimental animals with pyloric obstruction that the stomach contents contain both sodium and chloride, but because the chloride loss exceeds that of sodium, that alkalosis results (1). More recently, in addition to extracellular water and electrolyte deficits, intracellular deficits of potassium-and partial replacement of these deficits by sodiumhave been demonstrated in experimentally induced alkalosis $(2,3)$, and in patients with alkalosis from vomiting (4). This report describes abnormalities of water and electrolyte metabolism, and discusses some mechanisms of their production, in patients with alkalosis resulting primarily from loss of upper gastrointestinal contents. Renal insufficiency, which occurred in a number of them, was the subject of a previous report (5).

\section{CLINICAL MATERIAL AND METHODS}

The patients usually were seen shortly after hospital admission and were observed at frequent intervals thereafter. In the patients who were studied fairly extensively (Cases 1 through 4) there had been in each instance vomiting due to obstructing duodenal ulcers for periods varying from several days to several months prior to admission. Fluid and electrolyte losses before admission, therefore, varied widely and were in each instance unknown. Continuing losses after admission were measured, but since all patients were studied on open wards, collections of urine and gastrointestinal secretion were subject to some error, with occasional regrettable losses of entire specimens. In the larger series of patients where electrolytes in the serum only were studied, the alkalosis was

\footnotetext{
1 Part of this work was done under contract with the Army Medical Research and Development Board, and during the tenure of a Life Insurance Medical Research Fellowship.

2 Life Insurance Medical Research Fellow.

Senior Fellow, National Institutes of Health.

- Commonwealth Fund Fellow.
}

in each instance thought to be due to loss of upper gastrointestinal secretion, although the cause was not invariably pyloric obstruction.

Standard chemical methods for blood, urine, and gastrointestinal secretions were employed: carbon dioxide content (6) ; chlorides (7) ; phosphorus, modified for colorimetric determination (8); non-protein nitrogen (6); total urinary nitrogen $(6)$; creatinine $(9)$; calcium (10). In Case 1 sodium and potassium were determined chemically $(11,12)$. All other sodium and potassium determinations were made with a Perkin-Elmer Flame Photometer, Model 52A. Urine and serum sodium and urine potassium determinations checked in duplicate samples within $3 \mathrm{mEq} . / \mathrm{L}$., and serum potassium within $0.2 \mathrm{mEq} . /$ L. Urine and blood $\mathrm{pH}$ were measured by glass electrode in a Beckman pH Meter without exposure to air and at room temperature, with a correction of $.01 \mathrm{pH}$ for each degree below $37^{\circ} \mathrm{C}$. Standard renal clearance methods were utilized (13). Urine was collected by an indwelling catheter and the bladder rinsed with distilled water at the end of each period. Glomerular filtration rate was measured by inulin clearance in Case 2 (13), and by endogenous "creatinine" in Case 4 (9).

\section{RESULTS}

Case 1 (J. G.) Severe Alkalosis and Renal Insufficiency: Refractory to large quantities of parenteral saline; improvement on addition of parenteral potassium

Additional clinical and laboratory data on this patient have been recorded elsewhere $(5,14)$. He was first seen after a prolonged period of continuous vomiting and alkali ingestion (Table I, Figure 1). On admission there were: coma; signs of extreme dehydration; oliguria; high serum carbon dioxide content; low serum chloride, sodium, and potassium; and high serum non-protein nitrogen. An aliquot of urine collected before any therapy was started contained $31 \mathrm{mEq}$./ L. of sodium, 40 of chloride, and 92 of potassium. There was, therefore, evidence of inadequate renal conservation of all three of these ions in the 
C. H. BURNETT, B. A. BURROWS, R. R. COMMONS, AND B. T. TOWERY

\begin{tabular}{|c|c|c|c|c|c|c|c|c|c|c|c|c|c|c|c|c|c|c|c|c|c|c|}
\hline & \multirow{2}{*}{$\begin{array}{l}\text { 莣 } \\
\text { ठే }\end{array}$} & \multicolumn{2}{|c|}{ 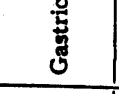 } & ही & & & & & & & & & & & & - & $1 \infty$ & 0 & 0 & 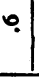 & $\infty$ & $\infty$ \\
\hline & & \multicolumn{2}{|c|}{ 站 } & हू. है & & & & & & & & & & & & $\infty$ & \begin{tabular}{|c|}
+5 \\
$\infty$ \\
$\infty$ \\
$\infty$
\end{tabular} & $\infty$ & $\begin{array}{l}\overline{\bar{\alpha}} \\
\bar{a}\end{array}$ & $\stackrel{9}{\circ}$ & 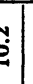 & $\stackrel{\infty}{\infty}$ \\
\hline & \multicolumn{3}{|c|}{ 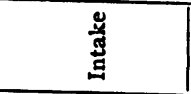 } & ह్రి & & & & & & & & & & & & 0 & 10 & $\stackrel{\circ}{\circ}$ & \begin{tabular}{|l}
$\bar{p}$ \\
0 \\
0
\end{tabular} & $\begin{array}{l}\infty \\
0 \\
0\end{array}$ & P & $\Xi$ \\
\hline \multirow{9}{*}{ 연 } & \multirow{6}{*}{$\vec{z}$} & \multirow{3}{*}{ 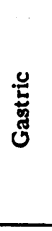 } & \pm & 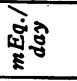 & & & & & & & & & & & & 0 & $\infty$ & 0 & 0 & $=$ & $\infty$ & - \\
\hline & & & $\ddot{z}$ & 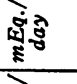 & & & & & & & & & & & & 0 & $\infty$ & 0 & 0 & $\simeq$ & $\infty$ & - \\
\hline & & & $\bar{\sigma}$ & 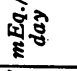 & & & & & & & & & & & & 0 & $\infty$ & 0 & 0 & $\approx$ & $\infty$ & $m$ \\
\hline & & \multirow{3}{*}{ 营 } & $\forall$ & बิें & & & & & & & & & & & & + & $\left|\begin{array}{|c|}\mathbf{b} \\
0\end{array}\right|$ & $\begin{array}{l}+ \\
0 \\
\end{array}$ & 8 & $\approx$ & î & లే \\
\hline & & & $\ddot{z} \mid$ & वेंत्रे & & & & & & & & & & & & + & $|\grave{\Delta}|$ & 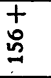 & 品 & $\infty$ & 81 & \& \\
\hline & & & $\overline{0}$ & बิंత్ & & & & & & & & & & & & + & $\mid t$ & $\begin{array}{c}+ \\
\infty \\
\infty \\
o \\
+1\end{array}$ & 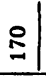 & $\stackrel{\infty}{-1}$ & $\approx$ & $\Xi$ \\
\hline & \multirow{3}{*}{$\begin{array}{l}\text { 㟧 } \\
\text { g }\end{array}$} & & & 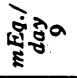 & $a$ & $\stackrel{\sim}{*}$ & al & 이 & 8 & 8 & 8 & 8 & 8 & 이 & : & 0 & 0 & 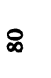 & 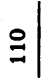 & ㅇ & 8 & $\stackrel{9}{\circ}$ \\
\hline & & & 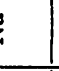 & 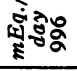 & $\left|\begin{array}{c}\infty \\
0\end{array}\right|$ & $\tilde{n}$ & 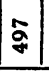 & $\$$ & 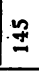 & 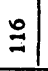 & \pm & ¿ & $z$ & $\stackrel{0}{\square}$ & $\vec{m}$ & $\mid \frac{\infty}{\sim}$ & $\mid$ & 膈 & $\infty$ & +1 & N & in \\
\hline & & & ; & ब్ํㅎㅀ & 啹 & $\tilde{\sim}$ & $\approx$ & $\cong$ & ڤั & $\cong$ & ڤั) & 号 & ટٌ & ¿े. & $\overrightarrow{0}:$ & $\stackrel{\infty}{\sim}$ & 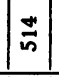 & 品 & $\stackrel{2}{2}$ & 0 & 8 & $\Xi$ \\
\hline & & & & 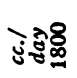 & . & 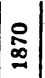 & : & ర్ల్ల & ठ্ల్లి & 0 & 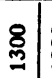 & छे & ڤ్ & 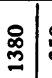 & 吕 & 0 & in & 0 & 0 & : & $\infty$ & ల్లి \\
\hline
\end{tabular}

空

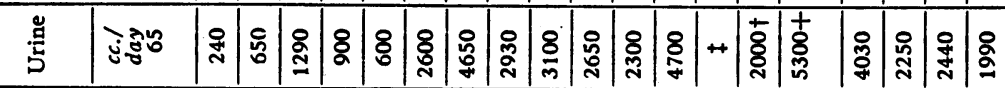

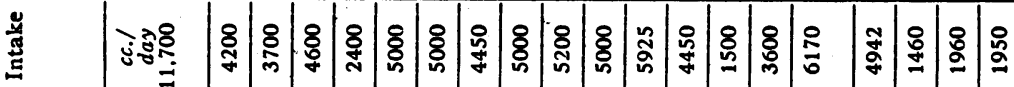

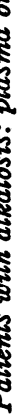

:

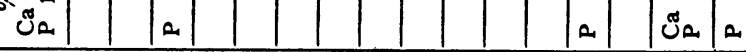

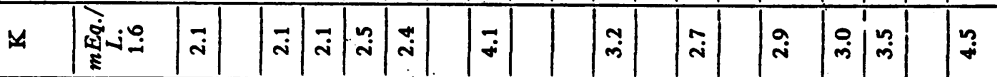

息

营

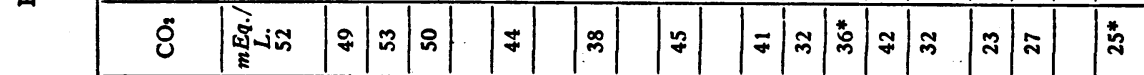

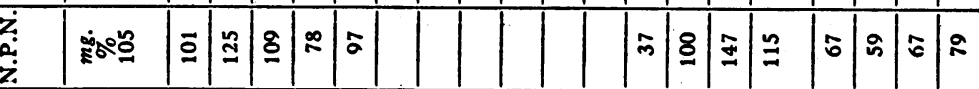

\begin{tabular}{|c|c|c|c|c|c|c|c|c|c|c|c|c|c|c|c|c|c|}
\hline శึ & - & N & $\mathrm{m} / \mathrm{o}$ & +10 & 10 & $n$ & $\infty$ & 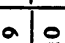 & - & N & m & $1-12$ & m & +1 & $\ln 1$ & 101 & $\ln$ \\
\hline ดี & 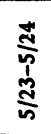 & 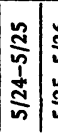 & 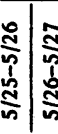 & 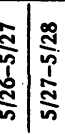 & 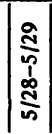 & 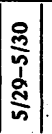 & $\mid \begin{array}{c}\bar{m} \\
\overline{0} \\
\frac{0}{m} \\
\bar{m}\end{array}$ & 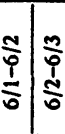 & \begin{tabular}{l|l}
$\frac{1}{0}$ \\
$\vdots$ \\
0 \\
0 \\
0
\end{tabular} & $\left|\begin{array}{l}\frac{2}{0} \\
\frac{1}{6} \\
6\end{array}\right|$ & $\mid \begin{array}{l}0 \\
0 \\
0 \\
0 \\
0 \\
0\end{array}$ & 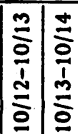 & $\frac{n}{3}$ & $\left|\begin{array}{l}0 \\
0 \\
0 \\
\vdots \\
\\
0 \\
0\end{array}\right|$ & 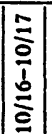 & \begin{tabular}{c|}
$\frac{\infty}{2}$ \\
$\frac{0}{1}$ \\
\\
0
\end{tabular} & $\frac{a}{\partial}$ \\
\hline 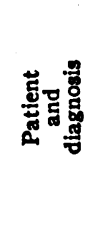 & & 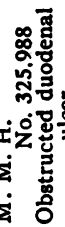 & & & & & & & & & & ن & 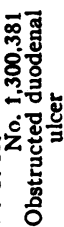 & & & & \\
\hline
\end{tabular}


STUDIES OF ALKALOSIS. II.

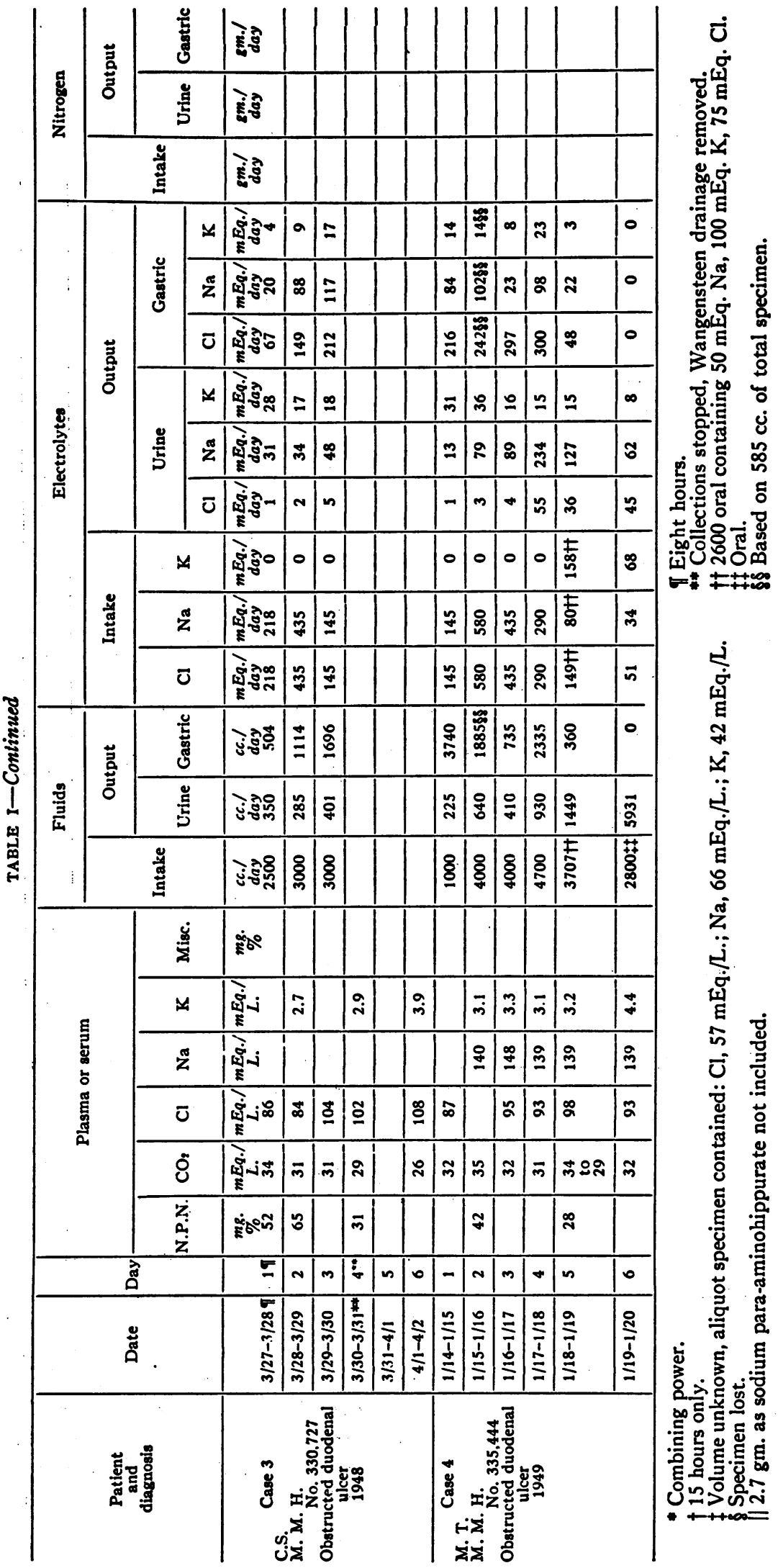



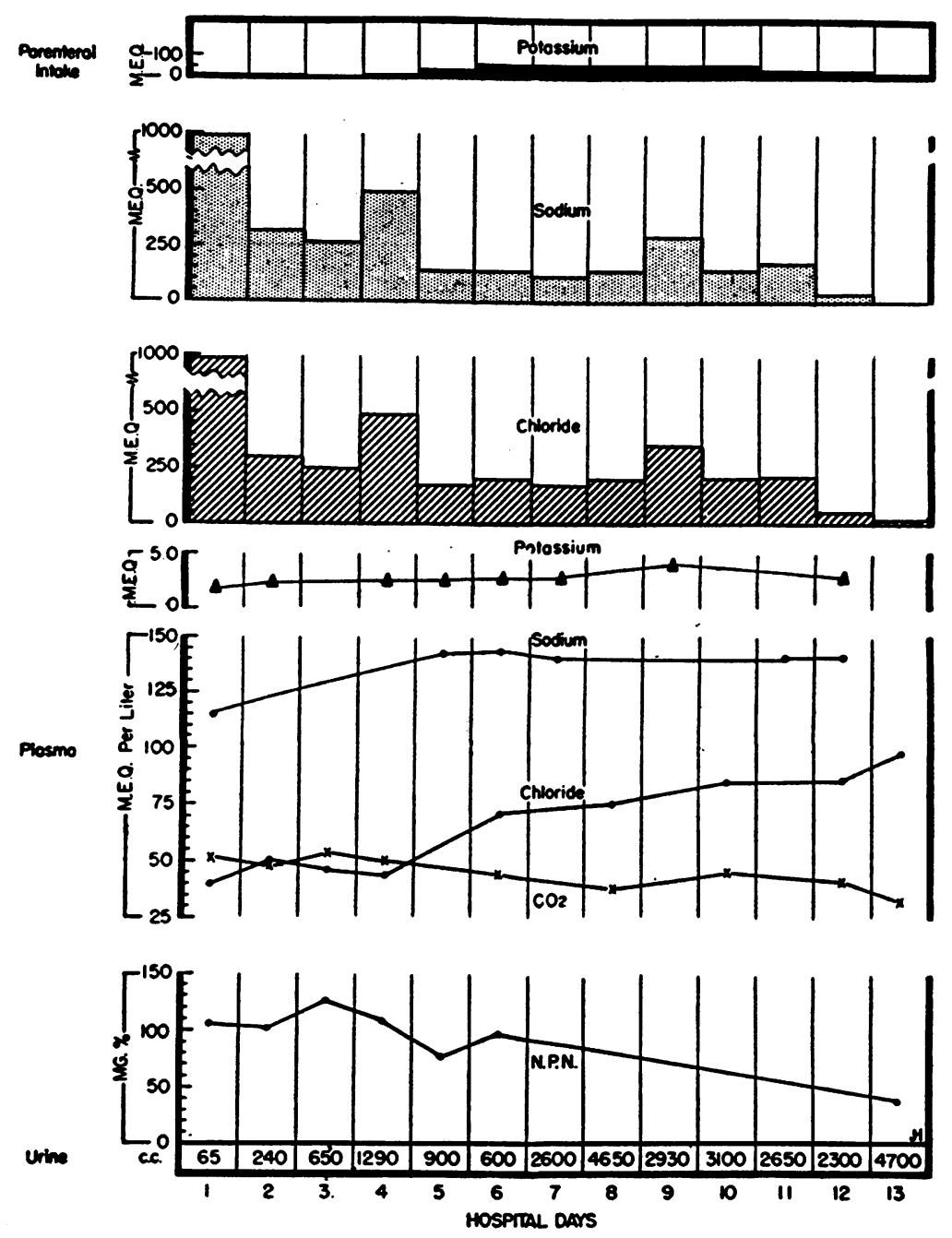

Fig. 1. Electrolyte Intake, Serum Electrolyte and Non-Protein Nitrogen Concentrations, and Urinary Output in Severe Alkalosis and Renal Insufficiency (Case 1)

presence of marked depletion of them in the extracellular fluid. During the first four days, the alkalosis failed to respond to 24 liters of water intravenously, 14 of which were isotonic saline. Fluid losses from the stomach and in the urine for the corresponding period were approximately 9 liters, and no stools were passed during the first nine days. By the fifth and sixth days the serum sodium was normal, the serum chloride had increased; nitrogen retention, alkalosis and hypopotassemia persisted; and urinary output remained quite low. Potassium in small quantities had been supplied parenterally since admission; but the intake of this cation was increased on the sixth day to $60 \mathrm{mEq}$. daily, while the sodium and chloride intakes were sharply reduced. Between the fourth and the sixth day definite and increasing clinical edema accumulated, and the patient remained disoriented. Consideration of intake and output figures plus these clinical factors render it unlikely, even in the absence of a controlled balance study, that insufficient fluid intake during this period accounted for the persistent oliguria. Between the seventh and 13th day the alkalosis improved, and 
urinary output increased markedly, exceeding the total intake on two days. Associated with this diuresis the edema subsided, the patient became oriented, and the serum electrolyte and non-protein nitrogen concentrations returned to normal.

Case 2 (J. C.) Severe Alkalosis and Renal Insufficiency: Hypopotassemia persisting after correction of alkalosis by saline and ammonium chloride

Additional data on this patient have been recorded in a previous paper (5). On admission the clinical and chemical findings resembled those of Case 1. The response to therapy differed in that following intravenous administration of sodium chloride, $224 \mathrm{mEq}$. of additional chloride as ammonium chloride on the second day, and water, there was a diuresis; and the hyponatremia, hypochloremia and alkalosis were corrected by the fourth day. Eighty $\mathrm{mEq}$. of potassium were given orally as milk on the third day. On the morning of the fourth day, hypopotassemia and azotemia were still present. After addition of potassium, both orally and parenterally, and a simultaneous reduction of sodium and chloride intakes, the serum potassium rose, and by the seventh day all serum electrolytes were normal. Nitrogen retention continued throughout the period of observation.

Complete collections were, unfortunately, not always obtained so that definite balances could not be calculated. Thus, the volume of the urine specimen on day one is unknown, on day two represents only a 15-hour specimen, and on day three is accurate probably within $200 \mathrm{cc}$.; urine collections thereafter were, we believe, accurate. Only two complete collections of gastric drainage were obtained on days five and seven. No stools were passed during the first seven days.

Urinary concentration of chloride was high on admission ( $57 \mathrm{mEq} . / \mathrm{L}$.) when serum concentration was $50 \mathrm{mEq}$./L. On the second day, following administration of 1.5 liters of isotonic saline the previous day, urinary chloride excretion was minimal. On the third day urinary chloride excretion increased markedly before serum concentration was restored to normal. Intravenous ammonium chloride administered late on the second day might have been responsible for this secondary rise in urinary chloride excretion.
A similar relatively high urinary concentration of sodium was present before hyponatremia was corrected (e.g., $96 \mathrm{mEq}$. of sodium were excreted during a 15-hour period on day two, whereas serum sodium was still low on day three, 122 $\mathrm{mEq} . / \mathrm{L}$.).

Urinary potassium excretion was significant throughout the period of observation, and highest when serum carbon dioxide content was highest and potassium lowest. Potassium and nitrogen excretions are compared in Table II, which covers days 4,5 and 6 when collections were sufficiently

TABLE II

Potassium and nitrogen balances in Case 2

\begin{tabular}{|c|c|c|c|c|c|c|c|c|}
\hline \multirow{2}{*}{ Day } & \multicolumn{2}{|c|}{ Intake } & \multicolumn{2}{|c|}{ Output } & \multicolumn{3}{|c|}{ Balances } & \multirow{2}{*}{$\frac{\text { Serum }}{\mathrm{K}}$} \\
\hline & $\mathbf{K}$ & $\mathbf{N}$ & $\mathbf{K}$ & $\mathbf{N}$ & Total & Total & 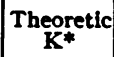 & \\
\hline $\begin{array}{l}4 \\
5 \\
6 \dagger\end{array}$ & $\begin{array}{r}m E q . \\
110 \\
20 \\
100\end{array}$ & $\begin{array}{l}\text { gms. } \\
6.3 \\
0.8 \\
0\end{array}$ & $\begin{array}{r}m E q . \\
63 \\
43 \\
39\end{array}$ & $\begin{array}{r}\text { gms. } \\
19.9 \\
9.6 \\
10.2\end{array}$ & $\begin{array}{r}\text { gms. } \\
-13.6 \\
-8.8 \\
-10.2\end{array}$ & $\begin{array}{l}m E q . \\
+47 \\
-23 \\
+61\end{array}$ & $\begin{array}{l}m E_{Q} . \\
+88 \\
+\quad 3 \\
+92\end{array}$ & $\begin{array}{c}m E q . / L \\
3.0 \\
3.5 \\
4.5\end{array}$ \\
\hline Totals & 230 & 7.1 & 145 & 39.7 & -32.6 & +85 & +183 & \\
\hline
\end{tabular}

* Three mEq. of potassium were assumed to have been liberated with each gram of nitrogen; therefore, the nitrogen deficit times 3 , plus the intake were theoretically available for replenishment of potassium deficit.

t Output is inaccurate on this day in that $180 \mathrm{cc}$. of vomitus were lost and are not included in the output calculations. This omission represents loss of negligible quantities of nitrogen and potassium.

accurate to permit balance calculations. Nitrogen balance was strongly negative, associated with little change in serum non-protein nitrogen.

Potassium balance for the three-day period was positive; but relatively large quantities of potassium were administered orally and parenterally (230 mEq.). Serum potassium rose from 3.0 to $4.5 \mathrm{mEq} . / \mathrm{L}$. An actual potassium uptake of 85 $\mathrm{mEq}$. occurred, but 63 per cent of the intake or $145 \mathrm{mEq}$. were excreted. If the assumption is made that $3 \mathrm{mEq}$. of potassium were liberated with each gram of nitrogen catabolized, and if the over-all balances only are considered, 98 of the $145 \mathrm{mEq}$. excreted reflected loss from cell breakdown, while 47 were in excess of protein loss.

However, this potassium being released into extracellular fluid during protein breakdown must also have been available as a source of potassium for recirculation and replenishment of intact but potassium deficient tissue. It can, therefore, be 
C. H. BURNETT, B. A. BURROWS, R. R. COMMONS, AND B. T. TOWERY

.

\begin{tabular}{|c|c|c|c|c|c|c|c|c|c|c|c|c|c|c|c|c|c|c|}
\hline & $\begin{array}{c}\frac{8}{x} \\
\left.\underset{x}{x}\right|^{a}\end{array}$ & & & $\begin{array}{l}0 \\
\dot{\sim} \\
\dot{n}\end{array}$ & $\left|\begin{array}{c}n \\
0 \\
m \\
m\end{array}\right|$ & & & $\stackrel{?}{\sim}$ & 吕 & 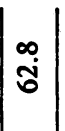 & 宓 & & 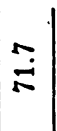 & 임 & 瓷 & & 趈 & 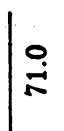 \\
\hline 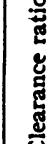 & 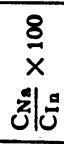 & & & in & $\mid \begin{array}{l}3 \\
0 \\
0\end{array}$ & & & $\mid \begin{array}{l}0 \\
0 \\
0\end{array}$ & Oे & $\mid$ & $\stackrel{\circ}{=}$ & & $\mid \begin{array}{l}n \\
\stackrel{2}{n}\end{array}$ & $\stackrel{\infty}{\underline{I}}$ & $\stackrel{n}{g}$ & & $m$ & \% \\
\hline & 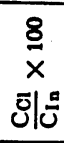 & & & $\mathcal{F}$ & $\left|\begin{array}{l}\infty \\
\dot{+}\end{array}\right|$ & & & $\left|\begin{array}{l}\infty \\
0 \\
0\end{array}\right|$ & $\mid$ & $\approx$ & $\stackrel{\infty}{\infty}$ & & $\mid$ & $\stackrel{\circ}{\stackrel{\Xi}{~}}$ & 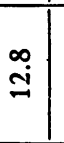 & & 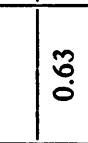 & $\underset{0}{N}$ \\
\hline & $\forall$ & 象: & $\stackrel{\infty}{\sim}$ & ஓ & $\approx$ & & & $\overrightarrow{0}$ & $\overrightarrow{\text { is }}$ & $\overrightarrow{0}$ & $\stackrel{\infty}{\Re}$ & & $\infty$ & n & ㅇ & & in & मे \\
\hline & $\tilde{z}$ & 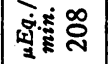 & $\stackrel{\infty}{\stackrel{2}{0}}$ & $\stackrel{R}{N}$ & 总 & & & $\frac{\infty}{0}$ & a & $\stackrel{2}{\sigma}$ & $\vec{a}$ & & $\hat{n}$ & 角 & $\hat{N}$ & & 흐 & $\equiv$ \\
\hline 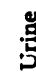 & ¿ & बู.ं & & $\vec{n}$ & $\mid \begin{array}{l}\infty \\
+\end{array}$ & & & $\ddot{B}$ & $\mid \begin{array}{l}4 \\
\end{array}$ & in & in & & 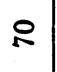 & $\hat{\sigma}$ & in & & & \\
\hline & $\bar{\tau}$ & बู่ & & $\widetilde{\sim}$ & $\exists$ & & & $\widetilde{\infty}$ & : & $\mid$ & $\overrightarrow{\mathrm{N}}$ & & $\frac{n}{n}$ & 草 & ठे & & $m$ & \pm \\
\hline & 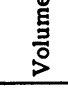 & 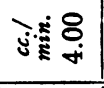 & $\left|\begin{array}{l}8 \\
+ \\
+i\end{array}\right|$ & $\left|\begin{array}{c}m \\
m \\
+\end{array}\right|$ & $\left|\begin{array}{l}0 \\
i \\
m\end{array}\right|$ & भ్ & $\left|\begin{array}{l}7 \\
\multirow{6}{*}{} \\
0\end{array}\right|$ & \begin{tabular}{|l}
$\hat{1}$ \\
in
\end{tabular} & $\left|\begin{array}{l}8 \\
0 \\
+\end{array}\right|$ & $\left|\begin{array}{l}\pi \\
+ \\
+1\end{array}\right|$ & $\vec{\sigma}$ & & 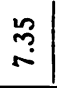 & \begin{tabular}{|c|}
$\begin{array}{c}m \\
0 \\
0\end{array}$ \\
\end{tabular} & ָָָ & & 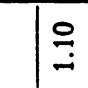 & 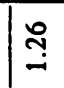 \\
\hline & s̊ & ن. & & q & ஓ & & & 3 & $\vec{m}$ & $\vec{m}$ & $\tilde{m}$ & & $\stackrel{p}{\circ}$ & oे & ㅇ & & $\approx$ & $\vec{N}$ \\
\hline & $\forall$ & 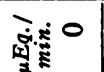 & 0 & 0 & 0 & 0 & 0 & 0 & 0 & $\approx$ & $\approx$ & $\alpha$ & $\approx$ & $\alpha$ & $\tilde{\alpha}$ & $\circ$ & 010 & 10 \\
\hline 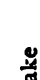 & $\ddot{z}$ & ब্ৰ: & 12 & $\Re$ & 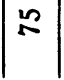 & \&્o & $\left|\begin{array}{c}\stackrel{\tilde{w}}{\sim} \\
\mid\end{array}\right|$ & 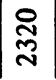 & $\left|\begin{array}{c}\stackrel{\sim}{\sim} \\
\text { | }\end{array}\right|$ & $\infty$ & $\infty$ & $\infty$ & $\infty$ & $\infty$ & 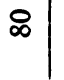 & ¿ूे| & $\begin{array}{l}0 \\
0\end{array}$ & 융 \\
\hline 5 & $\bar{u}$ & ब⿶凵 & 是 & 果 & 웜 & 0 & 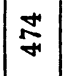 & $\frac{\pi}{5}$ & $\mid \begin{array}{l}\frac{\pi}{4} \\
+4\end{array}$ & $\Xi$ & $\cong$ & $\Sigma$ & 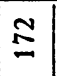 & $\cong$ & $\Sigma$ & $\frac{\infty}{\sim}$ & 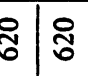 & 10 \\
\hline & 足 & $\begin{array}{l}0 \\
0 \\
0\end{array}$ & $\mid \begin{array}{l}\text { 음 } \\
\dot{\text { in }}\end{array}$ & \begin{tabular}{|l|} 
\\
$\dot{m}$
\end{tabular} & $\left|\begin{array}{|c|} \\
\dot{n}\end{array}\right|$ & i & \begin{tabular}{|l|} 
\\
in \\
.
\end{tabular} & \begin{tabular}{|l|} 
\\
$\dot{m}$ \\
\end{tabular} & 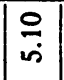 & \begin{tabular}{|l|}
8 \\
+4
\end{tabular} & $\begin{array}{l}8 \\
\\
\end{array}$ & \begin{tabular}{|l|} 
\\
+1
\end{tabular} & \begin{tabular}{|l|} 
\\
\\
\end{tabular} & \begin{tabular}{|l|}
8 \\
+
\end{tabular} & 8 & $\begin{array}{l}8 \\
\dot{0} \\
\end{array}$ & 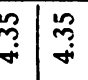 & $\stackrel{m}{\stackrel{m}{*}}$ \\
\hline & ¿ & 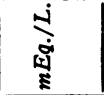 & & 9 & $\stackrel{\dot{i}}{\mathrm{i}}$ & & & 9 & 9 & $\stackrel{\infty}{-\infty}$ & $\stackrel{\infty}{\not}$ & & $\stackrel{\infty}{-\infty}$ & $\stackrel{\infty}{-\infty}$ & 9 & & & \\
\hline & $\forall$ & 窇品 & & $\dot{P}$ & $\mid \begin{array}{l}0 \\
\ddot{m}\end{array}$ & & & 品 & $\mid$\begin{tabular}{l|}
0 \\
\end{tabular} & $\mid \begin{array}{l}0 \\
\dot{m}\end{array}$ & $\ddot{i}$ & & $\vec{m}$ & $\overrightarrow{0}$ & $\vec{m}$ & $\mathcal{4}$ & $\underset{7}{*}$ & $\underset{7}{m}$ \\
\hline 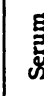 & $\ddot{z}$ & $\underset{0}{0} \stackrel{0}{=}$ & & $\stackrel{2}{m}$ & $\stackrel{\infty}{m}$ & & & $\stackrel{2}{=}$ & $\stackrel{m}{m}$ & $\stackrel{m}{=}$ & $\underset{m}{m}$ & & $\stackrel{m}{m}$ & $\stackrel{\stackrel{m}{*}}{*}$ & $\stackrel{\check{m}}{=}$ & 20 & $\frac{2}{7}$ & $\stackrel{\infty}{\dddot{m}}$ \\
\hline & $\bar{\sigma}$ & 密 & & $\hat{a}$ & $\hat{a}$ & & & $\hat{a}$ & $\hat{a}$ & $\approx$ & $\infty$ & & 2 & : & 요 & $\alpha$ & $\approx$ & $\approx$ \\
\hline & ర̊ & है & & $\tilde{\sim}$ & & & & & & & & & & & $\tilde{\sim}$ & $\underset{m}{\infty}$ & & \\
\hline & & $\tilde{\sigma}$ & $\stackrel{2}{\mathfrak{d}}$ & $\hat{\tilde{n}}$ & $\mid \begin{array}{c}0 \\
\frac{1}{1} \\
\frac{m}{m}\end{array}$ & $\begin{array}{l}\infty \\
0 \\
0 \\
0 \\
0\end{array}$ & $\left|\begin{array}{l}n \\
0 \\
0 \\
\infty \\
n\end{array}\right|$ & $\begin{array}{c}\tilde{\hat{\nu}} \\
\tilde{\infty}\end{array}$ & $\mid \begin{array}{c}\hat{a} \\
\grave{1} \\
\alpha\end{array}$ & $\left|\begin{array}{c}\frac{7}{7} \\
\frac{1}{0} \\
0\end{array}\right|$ & 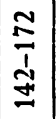 & 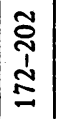 & 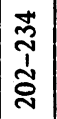 & 递 & 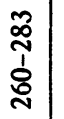 & & \begin{tabular}{c|c}
\multirow{N}{n}{} \\
\multirow{n}{*}{}
\end{tabular} & 象 \\
\hline & & & $\begin{array}{r}\bar{\sigma} \\
\dot{\tilde{\sigma}} \\
\dot{\delta}\end{array}$ & & & & & & & & & & & & & & 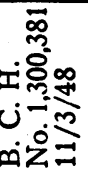 & \\
\hline
\end{tabular}


STUDIES OF ALKALOSIS. II.

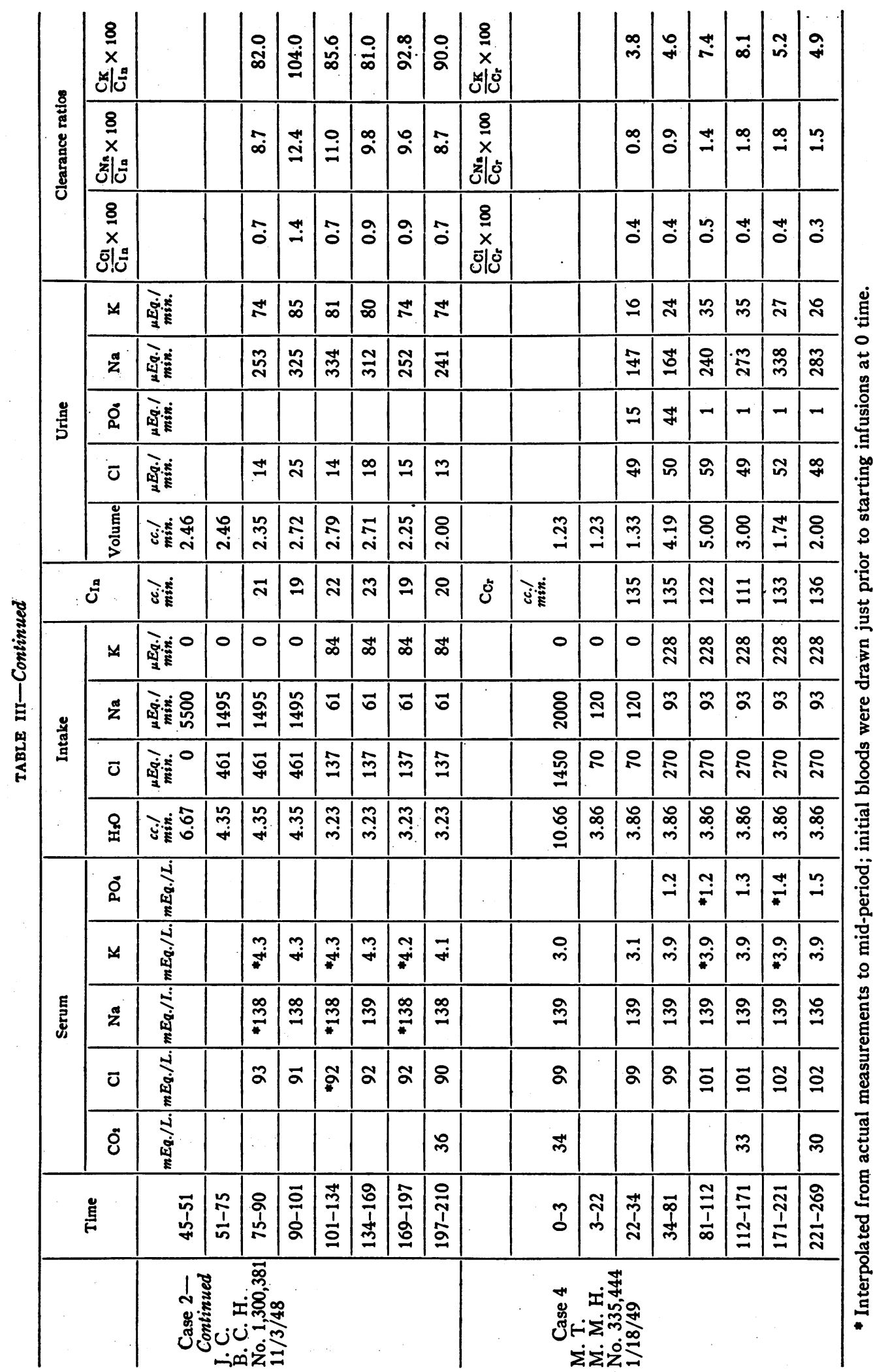


added to the quantity administered in food or as salts. If this potassium is considered, $98 \mathrm{mEq}$. then represent an endogenous source giving a theoretic positive balance of 183 instead of the observed $85 \mathrm{mEq}$.

From these data, plus those available for the first three days, it is reasonable to assume that during the entire six-day period of observation: 1. Potassium losses always exceeded those anticipated from protein catabolism. 2. Nitrogen balance was always negative. 3. Potassium uptake occurred and was a result both of administration of exogenous potassium and of utilization of endogenous potassium derived from protein catabolism. 4. Without provision of exogenous potassium, the amount of this base available from cell breakdown alone would have incompletely replaced the intracellular potassium deficit.

Serum electrolyte concentrations, rate of urinary electrolyte excretions, and rate of electrolyte intake were correlated with inulin clearance during an acute experiment on day four (Table III). The serum carbon dioxide content, chloride, and sodium were now normal, but serum potassium was still low. The increased excretions of sodium and chloride following administration of considerable quantities of these same ions intravenously (incident to renal clearance measurements, including Tm determination) were, therefore, anticipated. Urinary potassium excretion was relatively high but constant during the first hour when the rate of sodium intake was moderate. It increased significantly during the second hour coincident with a 30 -fold increase in rate of sodium administration ( associated with $\mathrm{Tm}$ determination). During the third to fifth hour sodium intake was sharply reduced, and potassium (as a solution of potassium chloride containing $23 \mathrm{mEq}$. of potassium per liter) was added. Urinary potassium excretion continued to increase, and attained rates twice those observed before the Tm measurement.

Clearance of inulin was greatly diminished throughout the test. Comparison of the $\mathrm{C}_{\mathrm{Ion}} / \mathrm{C}_{\mathrm{In}}$ ratios for sodium, chloride and potassium demonstrates that the increased urinary excretion of all three ions was associated with a similar percentage increase in all ratios. If one assumes that these ratios reflect the per cent of the filtrate excreted, it follows that excretion of sodium and chloride never exceeded 16 per cent of the quantity filtered; whereas 25 per cent of the potassium filtered was being excreted during the first hour, 50 per cent during the $T \mathrm{~m}$ determination, and 78 per cent within the first hour after sodium intake was reduced and potassium added to the infusion. The inference from these data is that renal conservation of potassium was inadequate, and that during the first part of the test, either sodium or chloride, or both, further inhibited tubular reabsorption of this cation. ${ }^{5}$ Addition of potassium to the infusion did result in some uptake of potassium, but less than 20 per cent of the intake was retained, and the $C_{K} / C_{i n}$ ratios remained at high levels, although they did diminish during the last hour of the test. If rates of potassium excretion during the acute experiment are calculated on the basis of 24 hours, the estimated output lies between 40 and $115 \mathrm{mEq}$. per day. The actual total urinary excretion for this day was $63 \mathrm{mEq}$. of potassium (Table I). Evidence has already been presented that throughout the seven-day period of observation in this patient, renal conservation of potassium was incomplete, in spite of good presumptive evidence of potassium lack. The data obtained during the acute experiment suggest that both sodium and potassium administration further augmented potassium excretion.

A similar test was performed three weeks later when serum carbon dioxide content was again elevated and chloride slightly reduced as a result of recurrent vomiting. Parenteral potassium chloride had been given for the previous six days, and serum potassium, low during the first test, was now normal. Sodium and chloride excretory rates were lower than observed during the first test, while potassium excretion was essentially unchanged. Clearance of inulin was approximately half that observed three weeks earlier.

\section{Case 3 (C.S.) Mild Alkalosis Responding Rapidly to Saline but Showing Continuing Hypopo- tassemia}

After a period of vomiting for four days, there were on admission mild alkalosis, hypochloremia, and azotemia. During the first 56 hours, 4.5 liters of normal saline and 4 liters of glucose in water were administered with prompt reversal of the al-

${ }^{5}$ See discussion below of limitations of clearance methods. 
kalosis. The serum potassium, low on admission, remained depressed. At this time gastric suction was stopped and food started; two days later the serum potassium had risen to $3.9 \mathrm{mEq}$./L. Note : The expected high chloride content of the gastric fluid, and conservation of this anion by the kidneys; that sodium losses from gastric aspiration were approximately half those of chloride; that urinary potassium excretion was significant despite hypopotassemia; and that there was a small but definite potassium loss from the stomach contents.

\section{Case 4 (M. T.) Mild Alkalosis, Hypopotassemia}

The initial course of this patient was similar to that of Case 3. Hypopotassemia persisted until potassium was supplied, following which the serum level rose and an uptake of $200 \mathrm{mEq}$. occurred over a two-day period. The results of renal function measurements done on the fifth day (Table III) are in contrast to those seen in Case 2. Sodium intake was limited throughout the experiment, and potassium, $59 \mathrm{mEq}$./L. as a solution of potassium chloride, was added after an initial control period. The rate of potassium administration was, therefore, almost three times that employed in Case 2. Note: The normal creatinine clearances; that potassium excretion, although it doubled, never exceeded $35 \mu \mathrm{Eq}$. per minute; that sodium excretion more than doubled during the test; that chloride excretion was low; and that serum potassium rose to normal, while carbon dioxide content fell during the test. The $\mathrm{C}_{\text {Ion }} / \mathrm{C}_{\mathrm{Cr}}$ ratios resemble those in Case 2, in that percentage increases for each electrolyte were similar. They differ in that actual $\mathrm{C}_{\mathrm{K}} / \mathrm{C}_{\mathrm{Cr}}$ ratios were very much less, although they did increase following potassium infusion.

Previous depletion of potassium apparently had occurred ( $c f$. moderately elevated urinary potassium excretion on the first two days), but renal conservation of potassium had sufficiently improved to allow retention of a relatively large proportion of that administered by the time the test was performed. The data obtained during this acute experiment suggest in addition a correlation between

42 SMMLTANEOUS SERUM CARBON DIOXIDE CONTENT AND POTASSIUM DETERMMNATIONS IN 18 PATIENTS

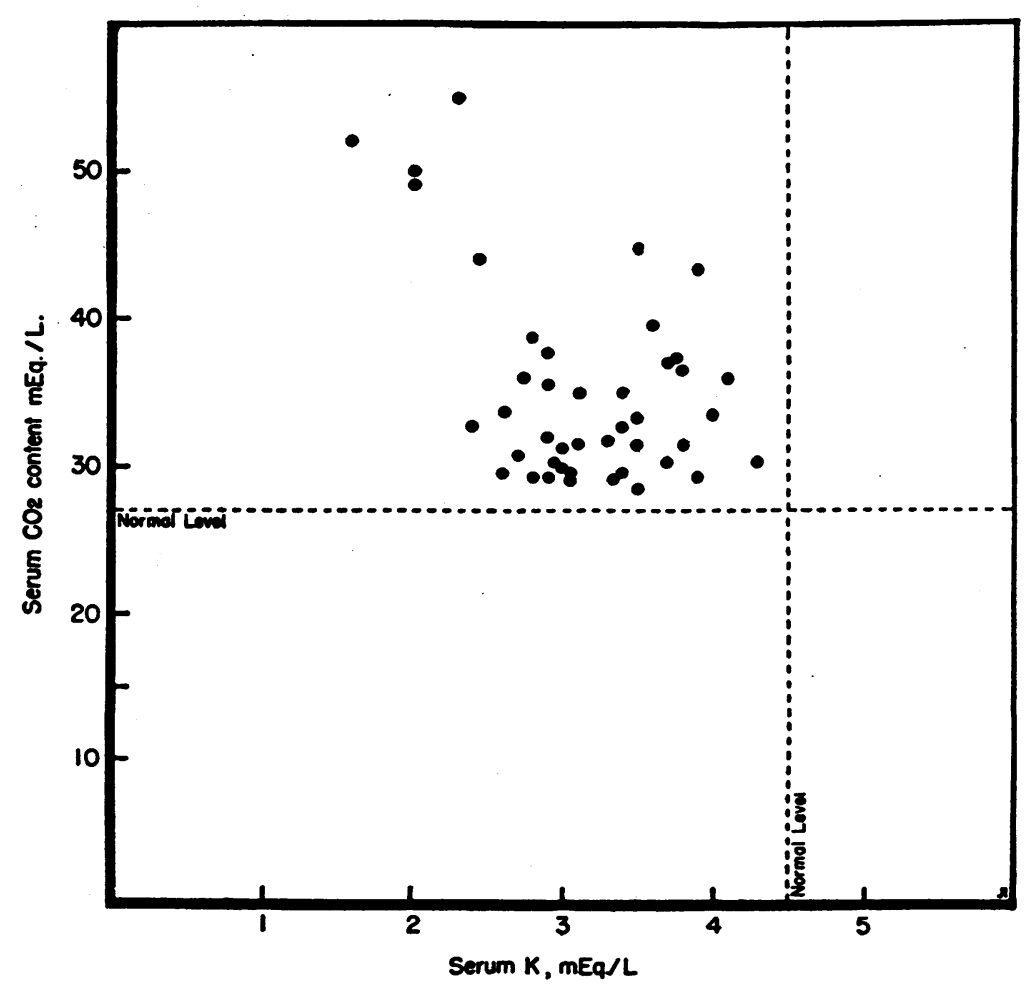

FIG. 2. 
sodium and potassium excretion, because intravenous potassium resulted in a significant increase in sodium excretion, whereas in Case 2 increased urinary potassium excretion followed sodium administration. The latter phenomenon occurs with normal renal function, and is frequently accentuated by renal disease $(15,16)$.

\section{Relation of Serum Potassium to Carbon Dioxide Content}

Figure 2 compares 42 simultaneous determinations of serum carbon dioxide content and serum potassium in 18 patients with alkalosis resulting from loss of upper gastrointestinal secretions. There is a suggestion that hypopotassemia accompanies alkalosis of this type; hyperpotassemia has not been observed by the authors in any such patient. However, it should be emphasized that these data do not demonstrate that the level of carbon dioxide content per se determines the level of serum potassium. For example, in Case 1 serum potassium varied from 1.6 to 4.1 (after administration of considerable potassium) with little change in carbon dioxide content. Hypopotassemia has also been clearly demonstrated during. acidosis (4). The measurements merely confirm the observations of others that hypopotassemia is a fairly regular occurrence in this syndrome (4, 17).

\section{DISCUSSION}

The data on these patients demonstrate the multiple nature of the biochemical abnormalities produced by loss or withdrawal of gastric contents. The removal of hydrochloric acid and water resulted in alkalosis, hypochloremia, and dehydration. With continued vomiting sodium concentration in stomach contents may reach half the chloride concentration. If gastric losses are only moderate and of short duration extracellular concentration of sodium may be maintained, due presumably to equivalent or greater removal of water as compared with sodium by the kidneys. The development of hyponatremia following continued or excessive vomiting, as seen in Cases 1 and 2 , must represent a break in the defense of extracellular concentration $(1,15)$. Shifts of intracellular water to the extracellular compartment, and sodium moving into the cells partially explain this dilution. Incomplete renal conserva- tion of sodium during continued gastrointestinal losses appeared from the observations in Cases 1 and 2 to contribute further to this extracellular cation depletion. A similar inability of the kidneys maximally to conserve chloride in the presence of extreme hypochloremia was also observed in these same cases.

In addition to these adjustments of sodium and chloride, marked changes in intracellular fluid may be inferred from hyperpotassuria, in excess of that liberated from protein catabolism, and hypopotassemia. The observations reported here are in keeping with clinical observations and with direct measurements of intracellular composition in alkalosis in which potassium deficiency has been demonstrated $(2,3,4,17)$.

The mechanism of the potassium deficiency is not clear. Darrow believes that the explanation lies in the fact that a "high serum bicarbonate in the serum must either facilitate the transfer of potassium out of the cells or increase the entrance of sodium," and that this occurs only after a biological steady state is attained. He discounts the possibility that increased urinary excretion of potassium could be the cause, because this same state was sometimes produced experimentally when the diet was abundant in potassium (3). Urinary potassium excretions were not measured, however. The data in this study have led the authors to the conclusion that excessive urinary potassium excretion must be an important factor in the production of deficit of this cation in alkalosis.

The exact mechanism by which renal loss is initiated and maintained is likewise obscure. Inability of the kidneys completely to conserve potassium, even with normal renal function, is one factor (18). Renal insufficiency, so commonly a feature of the syndrome, apparently accentuates this inability. Observations made in this laboratory indicate that in renal insufficiency of any type the $\mathrm{U} / \mathrm{P}$ ratio of potassium is usually five or more, even when hypopotassemia exists (19). These data do not contradict the conclusions of others $(20,21)$ that in renal insufficiency potassium excretory ability is impaired. In the absence of excessive intake or transfers of cell potassium due to catabolism the urinary potassium concentration in renal insufficiency is usually fixed at a higher level than in the normal. The effect of sodium, 
almost invariably employed therapeutically, could well perpetuate and extend any pre-existing intracellular deficit by further increasing urinary potassium excretion $(15,16)$. That other factors besides the excretion by the kidneys must also participate, however, is suggested by Case 4, in which excessive urinary potassium excretion was never demonstrated. The possibility that the acute episode with its accompanying dehydration and starvation, may stimulate the production of adrenal cortical steroids, which, in turn, have an effect on renal tubular control of potassium excretion, must be mentioned. The increased urinary potassium excretion following sodium administration, likewise, may be mediated through these glands. The data presented here furnish no information on this important point. Loss of potassium via the gastrointestinal tract, although not large, further contributed to the total deficits.

Interpretation of the clearance data is difficult. Any attempt to describe the renal tubular mechanism involved in electrolyte excretion depends upon accurate measurement of glomerular filtration rate. In the diseased kidney wide errors are possible, and could well explain the apparent renal tubular secretion of potassium observed in Case 2 . In addition, comparison of electrolyte clearance to inulin or creatinine clearance introduces further variables because electrolyte clearance (i.e., ratio of quantity excreted per minute to serum concentration) may well depend upon adjustments taking place between intracellular and extracellular fluid, for which the kidneys are not primarily responsible. With these reservations, the hypothesis that changes in $\mathrm{C}_{\text {Ion }} / \mathrm{C}_{\text {In }}$ or $\mathrm{C}_{\text {Ion }} / \mathrm{C}_{\mathrm{Cr}}$ indicate alterations in tubular activity is probably a fair approximation of actual adjustments taking place in the kidney (22). If this hypothesis is correct, the argument is strengthened that in alkalosis deficiency of potassium is a result partially at least of altered renal tubular activity in regard to control of excretion of this cation. If the increased potassium excretion observed in Case 2 were due to changes in glomerular filtration rate alone without change in tubular activity, an increase in filtration rate of almost one-half the observed inulin clearance would have been required. The data reported here do not permit a differentiation between decreased reabsorption, or the alternative explanation of increased tubular secretion of po- tassium $(23,24)$. The responses to the sodium load administered incident to $\mathrm{Tm}$ determination in Case 2 correspond rather closely with those which follow large infusions of sodium bicarbonate in patients with chronic glomerulonephritis, and at least as regards potassium excretion showed the same general departures from the normal responses (16). The effect of the potassium load in Case 4 is more difficult to assess, because control measurements on normal subjects have not been accumulated. The data have been recorded here because of the rather striking effect on sodium excretion, suggesting an unexplained correlation of renal control of sodium and potassium.

The nature of the renal insufficiency has been described (5). As stated there, the evidence indicates that acute renal functional changes are associated with the alkalotic episode.

Treatment of this syndrome should be directed towards correcting all of the observed biochemical abnormalities. Isotonic saline, glucose, and solutions of potassium chloride, containing 30 to 60 $\mathrm{mEq}$. of potassium, have met these needs (14). Once extracellular dehydration has been corrected, immoderate use of sodium chloride is to be avoided.

\section{SUM MARY}

1. Multiple abnormalities of water and electrolyte metabolism in patients with alkalosis resulting from loss of gastric contents have included: dehydration, high serum carbon dioxide content, hypochloremia, hyponatremia, hypopotassemia, and azotemia.

2. Evidence has been presented that intracellular deficit of potassium is probably an important feature of the syndrome, and that this deficit is a result, in part at least, of excessive urinary excretion of potassium in association with moderate gastrointestinal loss and essentially no intake of the cation.

3. The data from these studies suggest that the hyperpotassuria was the result of a variety of phenomena affecting the renal tubular control of potassium excretion.

\section{ACKNOWLEDGMENTS}

The authors are indebted to Elizabeth Nolan, Constance Qua, Frances Scher and Norma Bake for their technical assistance. 


\section{BIBLIOGRAPHY}

1. Gamble, J. L., and Ross, S. G., The factors in the dehydration following pyloric obstruction. J. Clin. Invest., 1925, 1, 403.

2. Darrow, D. C., Changes in muscle composition in alkalosis. J. Clin. Invest., 1946, 25, 324.

3. Darrow, D. C., Schwartz, R., Iannucci, J. F., and Coville, F., The relation of serum bicarbonate concentration to muscle composition. J. Clin. Invest., 1948, 27, 198.

4. Mudge, G. H., and Vislocky, K., Electrolyte changes in human striated muscle in acidosis and alkalosis. J. Clin. Invest., 1949, 28, 482.

5. Burnett, C. H., Burrows, B. A., and Commons, R. R., Studies of alkalosis. I. Renal function during and following acute alkalosis resulting from pyloric obstruction. J. Clin. Invest., 1950, 29, 169.

6. Peters, J. P., and Van Slyke, D. D., Quantitative Clinical Chemistry. Vol. II: Methods. Williams \& Wilkins Company, Baltimore, 1932.

7. Wilson, D. W., and Ball, E. G., Study of estimation of chloride in blood and serum. J. Biol. Chem., 1928, 79, 221.

8. Fiske, C. H., and SubbaRow, Y., Colorimetric determination of phosphorus. J. Biol. Chem., 1925, 66, 375.

9. Brod, J., and Sirota, J. H., The renal clearance of endogenous "creatinine" in man. J. Clin. Invest., 1948, $27,645$.

10. Fiske, C. H., and Logan, M. A., Determination of calcium by alkalimetric titration; precipitation of calcium in presence of magnesium, phosphate, and sulfate, with applications to analysis of urine. J. Biol. Chem., 1931, 93, 211.

11. Folin, O., Laboratory Manual of Biological Chemistry with Supplement. Appleton-Century Co., Inc., New York, 1934, Ed. 5.

12. Butler, A. M., and Tuthill, E., An application of the uranyl zinc acetate method for determ nation of sodium in biological material. J. Biol. Chem., 1931, 93, 171.
13. Goldring, W., and Chasis, H., Hypertension and Hypertensive Disease. The Commonwealth Fund, New York, 1944.

14. Burnett, C. H., and Burrows, B. A., Repair solutions in the treatment of metabolic acidosis and alkalosis. Med. Clin. North America, 1948, 32, 1293.

15. Gamble, J. L., Chemical Anatomy, Physiology and Pathology of Extracellular Fluid. Harvard University Press, Cambridge, Mass., 1949, Ed. 5.

16. Burnett, C. H., Burrows, B. A., and Commons, R. R., The lack of correlation between glomerular filtration rate and serum electrolyte concentration changes, urinary electrolyte excretion, or edema formation following sodium loads in subjects with normal kidneys, glomerulonephritis, and the nephrotic syndrome. J. Clin. Invest., 1949, 28, 773.

17. Pearson, O. H., and Eliel, L. P., Postoperative alkalosis and potassium deficiency. J. Clin. Invest., 1949, 28, 803.

18. Tarail, R., and Elkinton, J. R., Potassium deficiency and the role of the kidney in its production. $\mathrm{J}$. Clin. Invest., 1949, 28, 99.

19. Burrows, B. A., Commons, R. R., and Burnett, C. H., Sodium and potassium excretion in patients with renal insufficiency. Am. J. Med., 1949, 7, 423.

20. Elkinton, J. R., Tarail, R., and Peters, J. P., Transfers of potassium in renal insufficiency. J. Clin. Invest., 1949, 28, 378.

21. Keith, N. M., and Burchell, H. B., Clinical intoxication with potassium: its occurrence in severe renal insufficiency. Am. J. M. Sc., 1949, 217, 1.

22. Kattus, A. A., Sinclair-Smith, B., Genest, J., and Newman, E. V., The effect of exercise on the renal mechanism of electrolyte excretion in normal subjects. Bull. Johns Hopkins Hosp., 1949, 84, 344.

23. Berliner, R. W., and Kennedy, Thomas J., Jr., Renal tubular excretion of potassium in the normal dog. Proc. Soc. Exper. Biol. \& Med., 1948, 67, 542.

24. Mudge, G. H., Foulks, J., and Gilman, A., The renal excretion of potassium. Proc. Soc. Exper. Biol. \& Med., 1948, 67, 545. 